\title{
Economic impacts of innovations in tourism marketing
}

\author{
Dalia Streimikiene \\ Mykolas Romeris University, Faculty of Public Governance and Business, Vilnius, Lithuania \\ e-mail: dalia@mail.lei.lt \\ Elena Korneeva \\ Togliatti State University, Togliatti \\ Financial University under the Government of the Russian Federation, Moscow, Russia \\ e-mail: korneeva1207@yandex.ru
}

\begin{abstract}
Citation: Streimikiene, D., Korneeva, E. (2020). Economic impacts of innovations in tourism marketing. Terra Economicus, 18(3), 182-193. DOI: 10.18522/2073-66062020-18-3-182-193
\end{abstract}

Our paper tackles the novel issues of the economic impacts and innovations in tourism marketing in the 21st century. The paper examines the economic impact of tourism and its influence on the economy and the tourism industry in general from the angle of innovations in the tourism marketing and the new challenges for the tourism industry brought about by the COVID-19 pandemic that disrupted international tourism and caused major economic losses to the industry. We analyse the changes that the coronavirus pandemic made to the tourism industry and focus on the novel trends in tourism marketing that embeds the new informational technologies such as virtual reality (VR), augmented reality (AR), online Zoom tours, and other novelties that emerged after the lockdowns and social distancing imposed in the first half of 2020 in order to prevent the spread of the coronavirus infection. Our results show that tourism marketing in the 21st century should be based on sustainable management and provide the right answers to questions about the impacts of tourism on the economy without sacrificing positive economic growth. We also show that information technologies might offer viable alternatives to massive international over-tourism and package tours ensuring both the safety of travel and deeper immersion into the travel experience before, during, and after the trip. Our outcomes might be useful for tourism scholars, policymakers, as well as stakeholders specializing in international tourism marketing.

Keywords: tourism economics; sustainability; tourism marketing; innovations; economic impacts

JEL codes: Q2, L83, M10, M31

(C) Д. Стреймикиене, Е. Корнеева, 2020 


\title{
Экономическое влияние инноваций на туристический маркетинг
}

\author{
Далия Стреймикиене \\ Университет Миколаса Ромериса, Вильнюс, Литва \\ e-mail: dalia@mail.lei.lt \\ Елена Корнеева \\ Тольяттинский государственный университет, Тольятти \\ Финансовый университет при Правительстве РФ, Москва, Россия \\ e-mail: korneeva1207@yandex.ru
}

\begin{abstract}
Цитирование: Streimikiene, D., Korneeva, Е. (2020). Economic impacts of innovations in tourism marketing // Terra Economicus, 18(3), 182-193. DOI: 10.18522/2073-6606-2020-183-182-193

B нашей статье рассматриваются новые вопросы экономического воздействия и инноваций в маркетинге туризма в ХХ в. В документе исследуется экономическое влияние туризма и его воздействие на экономику и туристическую отрасль в целом с точки зрения инноваций в маркетинге туризма и новых вызовов для индустрии туризма, вызванных пандемией COVID-19, которая нарушила международный туризм и нанесла отрасли большой экономический ущерб. Мы анализируем изменения, которые пандемия коронавируса внесла в индустрию туризма, и сосредотачиваемся на новых тенденциях в маркетинге туризма, которые включают новые информационные технологии, такие как виртуальная реальность (VR), дополненная реальность (AR), онлайн-туры Zоот и другие новинки, которые возникли в результате изоляции и социального дистанцирования, введенных в первой половине 2020 года для предотвращения распространения коронавирусной инфекции. Наши результаты показывают, что маркетинг туризма в ХХ в. должен основываться на устойчивом управлении и давать правильные ответы на вопросы о влиянии туризма на экономику без ущерба для экономического роста. Мы также показываем, что информационные технологии могут предложить жизнеспособные альтернативы массовому международному туризму и пакетным турам, обеспечивая как безопасность путешествия, так и более глубокое погружение в путешествие до, во время $и$ после поездки. Наши результаты могут быть полезны для ученых в области туризма, политиков, а также заинтересованных сторон, специализирующихся на международном туристическом маркетинге.
\end{abstract}

Ключевые слова: экономика туризма; устойчивость; туристический маркетинг; инновации; экономические последствия

\section{Introduction}

International tourism offers viable economic solutions that do not sacrifice positive economic growth, but address issues such as sustainable management and provide answers to questions about the economic impact of tourism and its impact on the economy, 
without sacrificing any of these answers for positive economic growth (see Vasylchak, Halachenko, 2016; Radovic et al., 2017; Garau-Vadell et al., 2018; Lisin et al., 2018; Eslami et al., 2018; or Nasrollahi et al., 2020).

In the recent years, the number of tourists was growing steadily fuelled by the new visitors from China and India, in addition to the traditionally active tourists from the Western countries. One can see that tourism numbers and revenues are growing exponentially, as data from the World Tourism Organisation show (see Fig. 1 that follows).

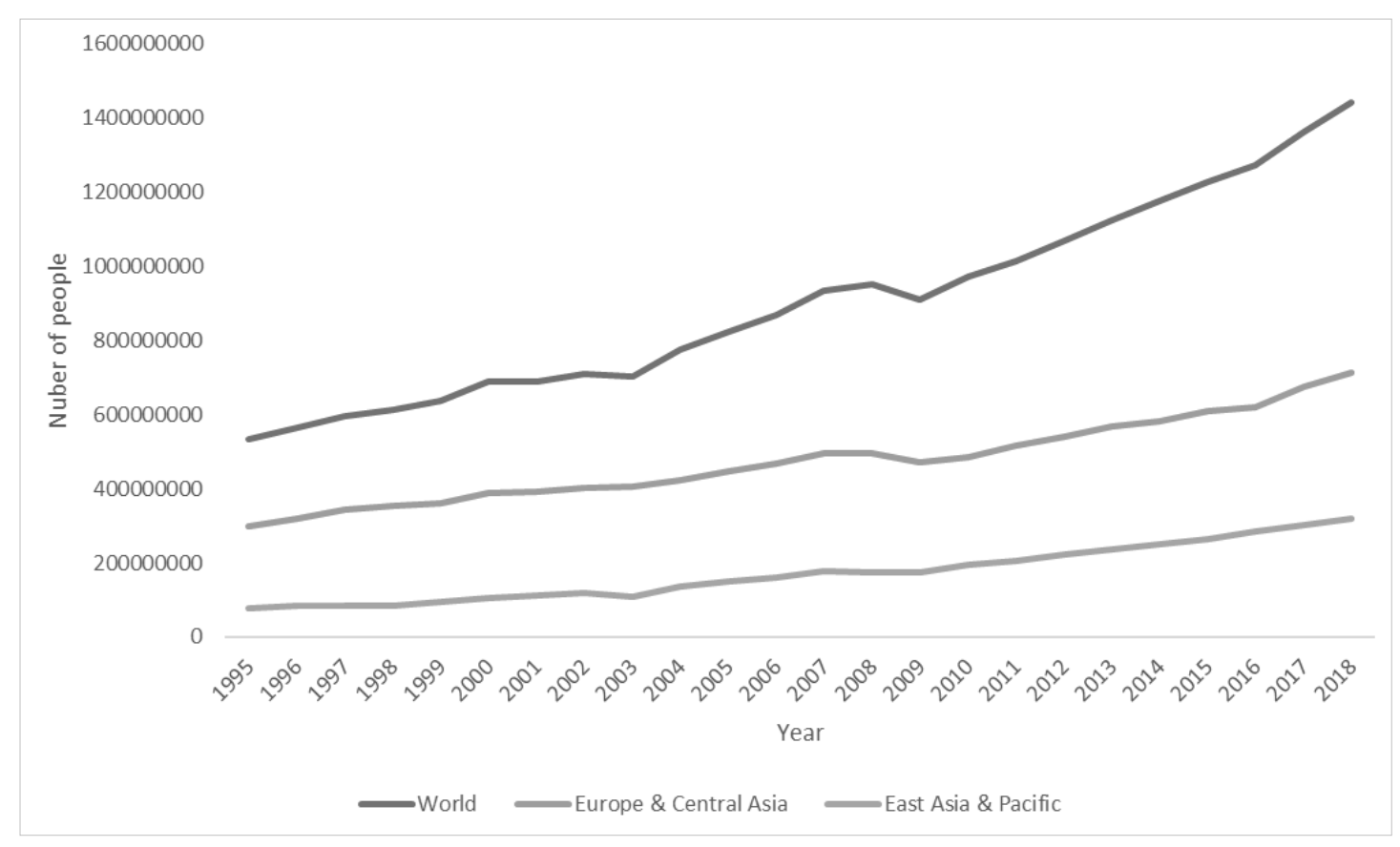

Fig. 1. International tourism, number of arrivals

Source: 0wn results based on World Bank (2020)

All of the above is happening due to the rising affordability of international travel for the wider masses, lifting border restrictions, and the increasing level of life in the emerging countries. However, another very important factor that boost international tourism and increases its economic gains is the rise of tourism marketing that embraces the novel technologies and innovations in the fields of information, psychology, sociology, and medicine, just to name a few, to promote tourism destinations and make more people to embark on a short or a long tourist trip either domestically or abroad (Divisekera, Nguyen, 2018).

Tourism has a wide range of economic effects, to which tourists contribute through sales, profits, tax revenues and much more (Tyslová et al., 2020). According to Li et al. (2018), tourism affects most economies and sectors through secondary effects, but according to Ahn and Back (2020), the most direct effects that occur in these sectors are in the tourism industry, such as hotels, restaurants, and resorts.

Many of the companies you encounter are multinational companies and internationally run organisations that contribute to economic losses, such as hotels, restaurants, hotels and resorts, airlines and hotels. While companies like Airbnb and Uber promote the growth of local communities, this is not always the case in the long term.

Many of the companies one can encounter in international tourism are multinational companies and internationally-run organisations, such as hotels, restaurants, hotels and resorts, airlines and hotels, that contribute to economic losses of the national economies. While companies like Airbnb and Uber promote the growth of local communities, this is not always the case in the long term. Most of the profits from the so-called «sharing econ- 
omy» are generated by the large multinational corporations in the long run. Thence, the losses to the international tourism might not that great when the sharing economy in tourism stops working.

Generally, one of the best tools for quantifying the economic contribution of tourism is the Tourism Satellite Accounts (TSA). They measure when the significant increase in the number of tourists is happening and when a subsequent decline in tourism follows (Ragab, Meis, 2016). This is because import inflation and increased demand are pushing up prices, taxes are potentially rising, and the government needs to fund expensive tourist infrastructure. The TSA measures direct impacts, while indirect induced impacts are assessed using a modelling approach and indirect effects (e.g., the impact of tourism on tourist infrastructure). Foreign tourists pump money into the local economies when they spend their euros or dollars on services and souvenirs made by locals at tourist destinations. The economic contribution of tourism is also felt in the local economy, where direct economic effects are generated when goods such as hotels, restaurants, hotels and drinks are sold. Moreover, the indirect economic impact of tourism is reflected in investment and expenditure by private and state interests in the context of tourism. The economic position of tourism cannot be fully understood without playing an important role in the country's wealth. Tourism is an exceptional intermediary in the growth of an economy and is therefore an important component at macroeconomic level. Many countries have identified tourism as the most important way to boost their economies. The more economically developed countries (MECs) benefit from tourism in terms of produced wealth, even if the GDP that tourism generates is low. Lower developing countries (LEDCs) are volatile in their participation in tourism, but receive money from the majority of countries. Some economies have suffered from the economic crisis of recent years, particularly in the tourism sector. This leaves their local tourism industry vulnerable to anything that negatively affects it, with devastating effects on the overall economic climate.

Any society can benefit from tourism if it is sustainable for society. Tourism could make a considerable contribution to this, given the government's efforts to eradicate poverty and diversify the economy. However, the economic benefits of tourism depend on the appropriate and reasonable amenities the country offers.

Recent COVID-19 pandemic that happed in 2020, brought many new challenges and restrictions to the tourism industry causing harsh damages to its structure and mechanisms. There are many new issues tourism professionals around the world need to face. Due to that, tourism marketing in the post-pandemic world should adapt to these new challenges and introduce tools and techniques that would help the industry to recover and achieve positive economic growth.

This paper is structured as follows: Section 2 describes the current information technologies and the best practices of their use in tourism marketing. Section 3 analyses the impact of COVID-19 on international tourism and travel. Section 4 elaborates on the virtual and augmented reality in tourism. Section 5 describes the impact on coronavirus pandemic on the online resources used in tourism marketing. Finally, the Conclusions close this paper and offer some insights and perspectives of this research.

\section{Information technologies and tourism marketing}

Generally, sustainability is boosting tourism, and smart tourism is becoming a driver of social change (see, e.g., Khan et al., 2017; Dabeedooal et al., 2019). The challenges and opportunities for tourism services offered by small and medium-sized tourism companies, which are usually run by families, are many and varied. Data of this kind can benefit tourism authorities, businesses and the tourism sector in many ways. The fact that hotels often have more data on their guests than hotels in most countries, for example, shows that effective marketing of tourist resources is also essential to reduce resource waste. In short, 
precise and accurate data (as well as tools for their processing and analysis) are crucial for planning and communication in tourism industry (Abbott et al., 2012; Huamin, Xuejing, 2019; Vitic Cetkovic et al., 2019,). This also opens the issue of the so-called "big data" and their usage. As more and more people are using digital technologies in the devices such as smartphones and digital trackers, the data from these devices can be aggregated and analysed quickly. However, the amount of information collected in such a way is enormous and requires special tools and skills. This also constitutes a challenge for tourism analytics who need to be able to work with such data.

Based on analysis of the international tourism and tourism marketing, it is obvious that information and communication technology is having an impact on the tourism industry (see e.g. Chiabai et al., 2014; Abrham, Wang, 2017; Stanujkic et al., 2019). These findings can be of great help to the decision-making process and improve its functioning. With more data - driven figures and more information available - tourism stakeholders can make informed decisions. For example, the Nepal Government can offer people in rural areas training on how to improve the use and effectiveness of information and communication technology. Nepal which is a popular tourism destination and boasts the highest mountains in the world and pristine and beautiful nature, has stressed that many people in tourist areas still follow the old business methods. When new technologies are part of the problem, and peer-to-peer apps and social media encourage people to visit destinations, exit strategies can be offered (Kharel, 2018). London is one of the first countries to develop a technological approach to the problem, and an example of this is a city app called Play London.

In the Czech Republic, the smartphone apps are used to promote the diverse historical heritage of the country. One of the apps called «0peration Anthropoid» features a smartphone quest-like online game that uses the geolocation coordinates (Strielkowski, 2016).

Recent trends in United States tourism show that there is a strong correlation between the incentive for business travellers and pleasure. It is particularly useful that this is one of the most important factors in attracting tourists, whether they are travelling for business or pleasure. Instead of making forecasts, this data can be used to determine the actual situation of key markets. The tourism 4.0 platform facilitates this by using key technologies that were available at the time. In this way, the platform reduces the information selection congestion that is currently a challenge for tourism companies in the United States, Europe, Asia, and the Middle East. In addition, the platform can be used by various tourism providers to exchange information about tourist products and services such as hotels, restaurants, hotels and resorts.

Tourism 4.0 uses new services and products developed to the satisfaction and experience of all stakeholders in the tourism ecosystem (Kurgun et al., 2018). The information technology used in the tourism industry and its impact on tourism are very important. Tourists use technology to support decisions - during their journey and at their destinations. There are numerous applications of information technology in sectors such as travel, tourism, hospitality, business, education, health and health care, and tourism management.

One of the challenges facing the industry is that the growth in tourism to destinations around the world is being felt more strongly by less populated areas. Although we account for more than one-third of all tourist arrivals in the United States, those with the greatest impact, measured by the intensity of tourism, face greater impacts. Tourism intensity is measured by visit arrival data in combination with data on the size of the resident population.

\section{COVID-19 and international tourism}

Right after its outbreak in March 2020, the World Travel and Tourism Council has warned that the COVID-19 pandemic could destroy millions of jobs in the travel and tourism sector, with the global decline in travel expected in 2020. Unfortunately, this was quite precise. 
International tourism suffered immensely from the coronavirus-caused restrictions and in some places, it came to an ultimate halt.

COVID-19 is not an ordinary shock to global tourism, but there is no analogy in the history of the massive expansion of international tourism that began in 1950. As highlighted, UNWTO (2020) predicts that the impact of COVID 19 on the global travel and tourism sector (WTTC) would result in an annual loss of 1.5 to 2 billion dollars in tourism revenues in 2020. The estimate for the WTTC 2020 is much higher and expects to have an impact on tourism of $\$ 3$ to $\$ 5$ billion per year by 2020 .

Figure 2 that follow below shows the abrupt change in the international tourist arrivals offering a comparison of 2019 and the first quarter of 2020.

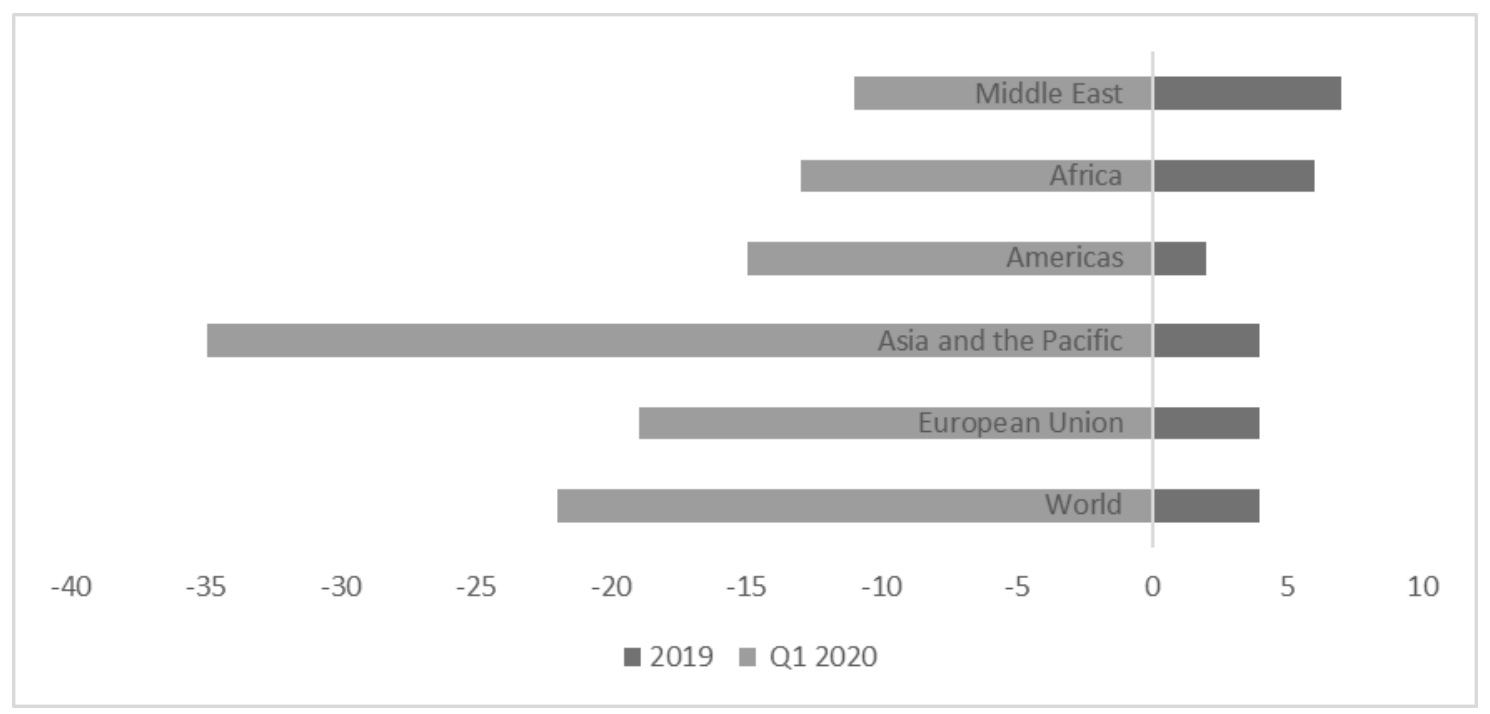

Fig. 2. International tourist arrivals, 2019 and 012020 (in \% change) Source: own results based on UNWTO (2020)

A recent study by the World Health Organization (WHO) and UNICEF shows that a near-total ban imposed in response to pandemics has led to an increase in travel to countries with high food insecurity, especially compared to 2019. The COVID-19 pandemic suspended many practices of intangible cultural heritage and many World Heritage properties have been closed or closed because they are socially dissociated from communities living near the sites and have no access to them. Apart from that, the COVID-19 pandemic has brought travel to a standstill, and some $90 \%$ of the world's population lives in countries with travel restrictions. Given the widespread travel restrictions around the world, this suggests a significant impact on the global tourism industry as a whole. Although pandemics are well known to have affected many industries, they have also left a deep hole in the balance sheet of global tourism, which actually contributes more than $10 \%$ to global GDP. According to a statement released by the agency, this means that COVID-19 will lose five to seven years of growth, taking market trends into account. For its part, the government plans to resume travel from September 2020, rather than going into the fast lane. As in the world, the pandemic has also destroyed tourism, which contributes up to $8.2 \%$ to the economy in South Africa each year and employs one worker in over twenty. The background to this is a sharp decline in tourism spending in recent years, largely due to the economic downturn in China and India.

The travel industry has come to a sudden halt as travellers cancelled or rescheduled trips, and travel agents say the trip will be cancelled. According to the World Tourism Organization, the pandemic has resulted in a loss of $\$ 1.5$ billion in international tourism in 
South Africa alone. This means a loss of $\$ 320$ billion in international tourism revenue and a loss of more than two million jobs in the United States alone (OECD, 2020).

COVID-19 was created at the height of the winter cruise ship season, cruise ships are turning away from the Caribbean as the virus spreads, and it is going to have a lasting impact on the travel industry for the next several months and perhaps years. It is highly likely that it might encourage a change in the way travellers' approach and plan their journeys, but will it have a lasting impact on tourism? Europe has already lost more than a third of its cruise ship and air travel capacity since January 2020, and airlines are suffering from a sharp decline in activity (European Commission, 2020). As a result, some airlines have already made contingency plans in case of possible bankruptcy and are flying empty-handed. We would not have thought so a year ago, but people are already embracing the concept of slow, sustainable tourism. This unprecedented pandemic also provides an opportunity to question the importance of globalised tourism and invites us to rethink the new beginning of the tourism industry.

The pandemics have temporarily prevented us from defining tourism as a level of visitor that negatively affects the local population. These negative effects can include overcrowding, over-tourism, lack of access to healthcare and poor quality of life. This dynamic is reflected in the negative impact of tourism on the health of local populations in different countries. To slow the spread of the virus, some countries have imposed travel restrictions, meaning that many people cannot buy flights for leisure or business trips.

To cut costs further, airlines must make layoffs and cut flights. For example, the Korea Association of Travel Agents is asking for government support to offset travel expenses for its members and other travel agencies (Pulsenews, 2020). Most holiday trips are made in the summer months, as gas prices are low and many people prefer to wait until the last minute to plan a trip due to uncertainty. Stays have become popular in the United States, where most people spend their holidays near where they live. The global immobility caused by the coronavirus pandemic crisis has seriously confused tourists, politicians and researchers. A recent report by the United States Department of Tourism stated that bookings and cancellations have increased and damaged the industry's image (Gössling et al., 2020). On the one hand, there is already growing speculation that the pandemic could trigger a permanent change in market behaviour that could radically change global travel patterns. This leads to the question of whether we are entering a new era of global tourism and tourism-centred economics. Indeed, evidence suggests that memories after a crisis or disaster tend to be shorter, and that things return to the status quo sooner rather than later.

This quick assessment gives an overview of the current state of global tourism-centred economy and discusses the impact of a pandemic on the global economy and travel behaviour in the coming years. Given the scale of the COVID 19 pandemic, it is worth rethinking the idea that we should not return to normal day-to-day business when and after a crisis. The pandemic also raises questions about vulnerability, as low-paying tourism jobs are disproportionately affected by crises, and early indications suggest that tourism will have a disproportionate and much larger impact in lower-income countries. COVID 19 offers us a powerful lesson on the effects of global change. Tourism plays an important role in the economic and social life of many of the world's poorest countries, from the Middle East to Africa. A response to tourism begins, leading to better planning and management to reduce its social and environmental impact. This has led to the creation of the concept of sustainable tourism, and interest in this concept has been increased by the slow implementation.

\section{Virtual and augmented reality in tourism}

In the last decade or so, the traditional computer mouse and touchscreen used for hotel and flight bookings have been replaced by virtual reality (VR) technology which can be found, for example, in VR headsets such as the 0culus Rift and HTC Vive or the cheap 
Google Cardboard headsets one can assemble for a price of several dollars. In addition, there is also a steep rise in the popularity of the augmented reality (AR), when only a part of the virtual reality is depicted on the background on the real images, buildings, and sceneries.

By having potential tourists with a clearer and more real vision of the trip, tourism and travel marketing specialists can put them in a better position to discover the world, experience the destination chosen and get to know the inhabitants and possibilities of this place. In order to experience the impossible in virtual reality, one must understand the power and power of the medium and play with it in the right way.

The desire to travel there was greater after travelling in virtual reality, and the VR experience aroused a thirst for travel when the viewer imagined he was there. These emotions help people make decisions, and VR itself plays an important role in the decision-making process. Once one decided whether or not to travel, she or he can use VR to find their dream destination.

One can see how VR (and AR) is changing the way we do things today, changing our travel and tourism habits. Many tourism researchers believe that VR can be a powerful tool to create unforgettable experiences in tourism, not only for consumers but also for the travel industry. VR can also be used to provide location-specific activities, by creating custom spaces or using existing spaces to develop concepts for virtual reality experiences. VR can also be used to promote destinations, allowing potential visitors to immerse themselves in a destination experience and learn more about it even before the visit (not speaking about revising those destinations after the visit in online mode without leaving the comfort of their homes). Virtual reality in tourism is enhanced by the unforgettable experience design framework. The overview of augmented and virtual reality offers seemingly endless possibilities to engage guests before, during and after travel to holiday destinations and far-flung places. The use of this technology opens up new opportunities for the travel and tourism industry to market itself and connect with guests. Tourist destinations and businesses around the world have tightened conditions for closures, providing screens to millions of customers to show a world of landscapes, attractions, tourism and activities that could encourage visitors once the crisis subsides. Tourism marketing specialists can use the technology to engage the potential customers and create unforgettable experiences. Virtual reality-based technology used to watch 360-degree videos of tourist destinations via a VR headset, provides an immersive experience of distress that undoubtedly stimulates the urge to travel and make new experiences. In addition, immersive experiences of places enable the viewer to gain confidence in travel by exploring and interacting with the projected environment. Although limited to the house, this new technology now allows people locked in their homes due to the COVID-19 pandemic to enjoy virtual tourism to replace a real trip for a while and to dream and plan their next (post-coronavirus) vacation. As people choose to travel less or not at all, there is a growing demand for the VR and AR in tourism. Virtual reality offers a risk-free way to escape the destination and travel in a safe and comfortable way. Following the outbreak of the coronavirus, virtual reality offered an immersive technology that could help accelerate the comeback of the travel and tourism industry. After the pandemic will be over, it is likely to stay and remain popular. As tourists become more climate conscious, it could become a great way to experience something new without the carbon footprint of pollution and overcrowding. With countries like India and Thailand creating their own immersive travel experiences, it might be time for other developed countries to do the same. There are a few more sectors that will benefit from VR travel technology and tools it offers travel agents and travellers. Although VR is not (or ever will be) as good as the real thing, it provides hotels, airlines, resorts, and tour operators with a marketing tool that no other medium can match. 


\section{Coronavirus pandemic and online resources for tourism marketing}

It is apparent that moving travel and related events to the Internet can reduce costs and carbon footprint, make participation more accessible to a wider audience, and reduce the cost to the potential guests. Companies and organizations stage virtual events through live tweets and live streaming on the Internet. Music festivals like Coachella in California opt out for YouTube livestreams due to the pandemic. Information technologies help people to enjoy music, art, courses, movies or other activities and to stay active and optimistic during the COVID-19 pandemic.

\section{SWOT analysis of post COVID-19 tourism marketing}

Table 1

\begin{tabular}{|c|c|}
\hline Strengths & Weaknesses \\
\hline $\begin{array}{l}\text { - Established protocols on how to market } \\
\text { tourist destinations in case of pandemics } \\
\text { and disasters. } \\
\text { - Using online tools for promoting tourist } \\
\text { destinations (e.g., online Zoom tours, or } \\
\text { applying VR and AR for familiarising peo- } \\
\text { ple with potential destinations. } \\
\text { - Acceptance and familiarity with online } \\
\text { tourism marketing tools }\end{array}$ & $\begin{array}{l}\text { - Abundance of online resources and promotion } \\
\text { which creates a plethora of information that } \\
\text { is hard to navigate at; } \\
\text { - Lack of physical experience with the destina- } \\
\text { tions and objects; } \\
\text { - Issues with projecting the "genius loci" or the } \\
\text { smells, sounds and other properties of popular } \\
\text { tourist destinations }\end{array}$ \\
\hline Opportt & \\
\hline $\begin{array}{l}\text { - Helping tourists to emerge into the desti- } \\
\text { nations before the visit offering them vir- } \\
\text { tual content. } \\
\text { - Using big data in identifying new fields } \\
\text { and areas for tourism marketing. } \\
\text { - Further development of ICT in tourism, } \\
\text { deepening of virtual tourism experience }\end{array}$ & $\begin{array}{l}\text { - Uncertainty and fear of international travel } \\
\text { due to future diseases and infections. } \\
\text { - Demise of popular travel services such as Air- } \\
\text { BnB or Booking due to the low demand and } \\
\text { recent shocks. } \\
\text { - Occurrence of another unexpected event that } \\
\text { would disrupt international tourism }\end{array}$ \\
\hline
\end{tabular}

\section{Source: 0 wn results}

Table 1 above offers a SWOT analysis of post COVID-19 tourism marketing that is likely to be shaped by the pandemic and all its related experience such as social distancing, increased hygiene, lockdowns, and travel restrictions.

One can see from Table 1 that among the obvious strength for the post COVID-19 marketing are the acceptance and familiarity with the online resources in tourism and hospitality. However, there are also weaknesses related to the disappearance of the traditional «taste and smell» approach to some destinations. One simply cannot sample the street food from a local market online or smell the cooking on the street.

Among the new opportunities are the use of big data and the further investments into the ICT services for tourism. However, there are also some threats related to how the travellers in post-coronavirus world are going to react to the possibility of contracting a disease while travelling. The global hysteria around the COVID-19 pandemic is likely to brew many fears that would damage the image of the tourism industry.

The virtual reality tour offers not only access to familiar cultural offerings, but also to new ones. Even traditional players in tourism industry realized the potential of online services thanks to the social distancing and lockdowns caused by the coronavirus pandemic. For example, the Louvre, a world-renowned museum located in Paris and housing many historical masterpieces and great works of art enabled interactive tours and even helped to create a route for the time when one is actually planning a visit. Online resources allow to visit any country in real time and help to plan the visit or to create specific itineraries. 
Online Zoom tours also provide a very choice for those visiting any country. They represent an interactive live experience that one can enjoy online from the comfort and security of her or his home or travel there in real time using an interactive map. The concept is that travellers travel in real time, while tracking the location of their destination, while providing them with personalised services. The online experience is very diverse and tries to address all aspects a traveller would gain from their trip. The special thing is that most tours do not take place in real time, but the host actually does the tour for you in real time. Sights around the world are published on their website to meet the travel needs. If one wants an interactive virtual journey, there are opportunities from Google Maps that feature photos and videos uploaded by the users to the professional guided tours (conducted either offline or in real time), as well as various interactive presentations created by the tourism boards and travel professionals. COVID-19 enriched the offer the tourism industry possessed and diversified the supply of online and offline services intended to support international tourism and hospitality industry while they are struggling with the outcomes of the pandemic and economic losses.

\section{Conclusions and implications}

Overall, it becomes apparent that COVID-19 pandemic disrupted international tourism and caused major economic losses to the industry. For the first time in many years people started to fear international travel and limit it to the minimum. Some even started to talk about the end of global tourism (or the end of globalisation). Business tourism and package tours alike suffered great economic losses and so did air carriers, hotels and restaurants. The blow to the tourism and hospitality industry caused by the coronavirus pandemic will continue to alter and to shape its further development in many years to come. Perhaps, most of the fears related to the demise of the tourism industry are never going to materialise but the pandemic will alter the rules of the game and the institutional setback of international tourism and travel worldwide. It is quite possible that global tourism would start putting more stress on sustainability and climate protection or embrace the sustainable development goals (SDG) to a greater extent than it ever did before.

However, from the ashes of the "old» tourism and travel industry, the new institutions of tourism are likely to emerge in accordance with the principles of the institutional design. These new institutions will be based on using more information and online communication technologies for promoting tourist destinations before, during, and after the visit. Moreover, some new players will emerge on the market offering novel solutions for booking accommodation, buying air and bus tickets online, and organizing experiences in various destinations. The «Blue 0cean strategy» will find its way into the post-pandemic tourism and travel and new economic niches will be formed on the newly recovered market.

All these changes should be tackled by the innovations in tourism marketing in the $21^{\text {st }}$ century that should embed them and use new tools and approaches for helping to return tourism and hospitality industry to the pre-pandemic levels. Economic well-being of many countries and the quality of life of many people around the world would very much depend on it. All of this, together with other important issues such as the global climate change, should become the new agenda for the tourism marketing and create a pathway for innovations that would help international tourism worldwide.

\section{References}

Abbott, A., De Vita, G., Altinay, L. (2012). Revisiting the convergence hypothesis for tourism markets: Evidence from Turkey using the pairwise approach. Tourism Management, 33(3), 537-544. https://doi.org/10.1016/j.tourman.2011.06.003 
Abrham, J., Wang, J. (2017). Novel trends on using ICTS in the modern tourism industry. Czech Journal of Social Sciences, Business and Economics, 6(1), 37-43. https://doi. org/10.24984/cjssbe.2017.6.1.5

Ahn, J., Back, K. J. (2020). The structural effects of affective and cognitive elaboration in formation of customer-brand relationship. The Service Industries Journal, 40(3-4), 226-242. https://doi.org/10.1080/02642069.2018.1460358

Chiabai, A., Platt, S., Strielkowski, W. (2014). Eliciting users' preferences for cultural heritage and tourism-related e-services: a tale of three European cities. Tourism Economics, 20(2), 263-277. https://doi.org/10.5367/te.2013.0290

Dabeedooal, Y. J., Dindoyal, V., Allam, Z., Jones, D. S. (2019). Smart tourism as a pillar for sustainable urban development: An alternate smart city strategy from Mauritius. Smart Cities, 2(2), 153-162. https://doi.org/10.3390/smartcities2020011

Divisekera, S., Nguyen, V. K. (2018). Determinants of innovation in tourism evidence from Australia. Tourism Management, 67, 157-167. https://doi.org/10.1016/j. tourman.2018.01.010

Eslami, S., Khalifah, Z., Mardani, A., Streimikiene, D. (2018). Impact of noneconomic factors on residents' support for sustainable tourism development in Langkawi Island, Malaysia. Economics and Sociology, 11(4), 181-197. https://doi.org/10.14254/2071789X.2018/11-4/12

European Commission (2020). Tourism and transport package. Available at: https:// ec.europa.eu/commission/presscorner/detail/en/QANDA_20_870

Garau-Vadell, J. B., Gutierrez-Taño, D., Diaz-Armas, R. (2018). Economic crisis and residents' perception of the impacts of tourism in mass tourism destinations. Journal of Destination Marketing \& Management, 7, 68-75. https://doi.org/10.1016/j.jdmm.2016.08.008

Gössling, S., Scott, D., Hall, C. M. (2020). Pandemics, tourism and global change: a rapid assessment of COVID-19. Journal of Sustainable Tourism, 1-20. https://doi.org/10.108 $0 / 09669582.2020 .1758708$

Huamin, L., Xuejing, Z. (2019). A Study of Factors of Leisure Tourism Intention: Based on the Theory of Planned Behaviour. Transformations in Business \& Economics, 18(1), 163-182.

Khan, M. S., Woo, M., Nam, K., Chathoth, P. K. (2017). Smart city and smart tourism: A case of Dubai. Sustainability, 9(12), 2279. https://doi.org/10.3390/su9122279

Kharel, S. (2018). Information and communication technology for the rural development in Nepal. Tribhuvan University Journal, 32(2), 177-190. https://doi.org/10.3126/tuj. v32i2.24714

Kurgun, H., Kurgun, 0. A., Aktaş, E. (2018). What does Web 4.0 Promise for Tourism Ecosystem? A Qualitative Research on Tourism Ecosystem Stakeholders' Awareness. Journal of Tourism and Hospitality Management, 6(1), 55-65. https://doi.org/10.15640/jthm.v6n1a6

Li, K. X., Jin, M., Shi, W. (2018). Tourism as an important impetus to promoting economic growth: A critical review. Tourism Management Perspectives, 26, 135-142. https://doi. org/10.1016/j.tmp.2017.10.002

Lisin, E., Shuvalova, D., Volkova, I., Strielkowski, W. (2018). Sustainable development of regional power systems and the consumption of electric energy. Sustainability, 10(4), 1111. https://doi.org/10.3390/su10041111

Nasrollahi, Z., Hashemi, M. S., Bameri, S., Taghvaee, V. M. (2020). Environmental pollution, economic growth, population, industrialization, and technology in weak and strong sustainability: using STIRPAT model. Environment, Development and Sustainability, 22(2), 1105-1122. https://doi.org/10.1007/s10668-018-0237-5 
OECD (2020). Tourism Policy Responses to the coronavirus (COVID-19) (https://www.oecd. org/coronavirus/policy-responses/tourism-policy-responses-to-the-coronaviruscovid-19-6466aa20/).

Pulsenews (2020). Korean tour industry seeks gov't help to prevent chain bankruptcies. Available at: https://pulsenews.co.kr/view.php?year=2020\&no=140795

Radovic, D., Strielkowski, W., Wang, J., Cepel, M., Rausser, G. (2017) Economic analysis of sustainable tourism: a case study of Nottingham. Transformations in Business \& Economics, 16(2B), 703-714.

Ragab, A. M., Meis, S. (2016). Developing environmental performance measures for tourism using a Tourism Satellite Accounts approach: A pilot study of the accommodation industry in Egypt. Journal of Sustainable Tourism, 24(7), 1007-1023. https://doi.org/10 $.1080 / 09669582.2015 .1107078$

Stanujkic, D., Karabasevic, D., Smarandache, F., Zavadskas, E. K., Maksimovic, M. (2019). An innovative approach to evaluation of the quality of websites in the tourism industry: A novel MCDM approach based on bipolar neutrosophic numbers and the hamming distance. Transformations in Business \& Economics, 18(1), 149-162.

Strielkowski, W. (2016). Innovations in tourism marketing: Operation Anthropoid in Prague. Marketing and Management of Innovations, (4), 106-112.

Tyslová, I., Abrhám, J., Horváthová, Z., Rubáček, F. (2020). Economic benefits of tourism: Cultural identity and tourism destinations in the Czech Republic. Terra Economicus, 18(2), 139-154. http://dx.doi.org/10.18522/2073-6606-2020-18-2-139-154

UNWTO (2020). International tourist numbers in 2020 (https://www.unwto.org/news/ covid-19-international-tourist-numbers-could-fall-60-80-in-2020).

Vasylchak, S., Halachenko, A. (2016). Theoretical basis for the development of resort services: regional aspect. International Economics Letters, 5(2), 54-62. https://doi. org/10.24984/iel.2016.5.2.3

Vitic Cetkovic, A., Bauk, S., Potocnik Topler, J. (2019). Assessing Caterers' Satisfaction with Cruise Tourists' Behaviour. Transformations in Business \& Economics, 18(1), 183-198.

World Bank (2020). International tourism indicators (https://data.worldbank.org/ indicator/ST.INT.ARVL). 